\title{
EBITDA vs. Cash Flows in Bankruptcy Prediction on the Polish Capital Market
}

\author{
Welc Jacek*
}

\begin{abstract}
:
One of the elements of company's evaluation is an analysis of bankruptcy risk metrics. In this study, the accuracy of bankruptcy predictions generated by EBITDA-based and cash flow-based liabilities-coverage ratios is evaluated within a sample of data from the Polish market. The study is based on a sample of 92 companies, in which case a bankruptcy filing was announced in a period between the beginning of 2009 and the end of the first half of 2016. The statistical analysis has confirmed the usefulness of the investigated liabilities-coverage ratios. Even though the sample covers wide variety of businesses, the logit models with only one ratio used as an explanatory variable are capable of identifying bankrupt firms (with one-period-ahead forecast horizon) in about $66-76 \%$ of cases. However, this research has not confirmed the supremacy of operating cash flows over EBITDA in predicting financial distress.
\end{abstract}

Key words: Bankruptcy prediction; Ratio analysis; Fundamental analysis; EBITDA; Operating cash flows; Coverage ratios.

JEL classification: G32, G33.

\section{Introduction}

An important part of ratio analysis is a computation and interpretation of metrics aimed at measuring the risk of bankruptcy, including profit-based or cash flowbased liabilities-coverage ratios. Coverage ratios which include operating profit or EBITDA (earnings before interest, taxes, depreciation and amortization) take into account only numbers from financial statements prepared on an accrual basis. Thus, they are deemed to be prone to aggressive accounting. In contrast, in ratios based on cash flows the inputs are derived from cash flow statement, which is deemed to be more immune to manipulations. Thus, theoretically, cash flow-based ratios should be more reliable than profit-based ratios. This research attempts to examine an extent to which EBITDA-based and cash flow-based coverage ratios are useful in a forecasting corporate failures. To this end, the accuracy of bankruptcy predictions generated by those ratios is evaluated within a sample of data from the Polish capital market.

The remainder of the paper is organized as follows. In the next section the relevant literature is discussed. Next the data and methodology used in the study are

\footnotetext{
Welc Jacek; Wroclaw University of Economics, Faculty of Economics, Management and Tourism, Department of Regional Economics, ul. Nowowiejska 3, 58-500 Jelenia Gora, Poland, <jacek.welc@ue.wroc.pl>.
} 
Jacek, W.: EBITDA vs. Cash Flows in Bankruptcy Prediction on the Polish Capital Market.

described. Then the section that presents the empirical findings follows. The paper closes with concluding comments.

\section{Literature Review}

EBITDA is calculated as the sum of operating profit and depreciation and amortization. It is often treated as a simplified surrogate of operating cash flows, because it adjusts the operating profit for expenses of a non-cash nature, that is depreciation and amortization (Mulford and Comiskey, 2002).

According to surveys, EBITDA-based ratios are by far the most popular type of accounting-based performance pricing in debt contracts. With such a use of EBITDA, the interest rate is often revised periodically, based on a grid of predetermined levels of the borrower's EBITDA-based ratios (Beatty et al., 2012; Beatty et al., 2015). EBITDA is also used in business valuation (Verninmen et al., 2005; Gray and Vogel, 2012; Hughen and Strauss, 2016), particularly of small private enterprises which do not report cash flow statement (Greenwald et al., 2001). The popularity of EBITDA is confirmed by a research, according to which EBITDA-based multiple is one of the two most frequently used valuation indicators by European stock analysts (Fernandez, 2002; Bancel and Mittoo, 2014; Lie and Lie, 2002). Due to its popularity, management boards of many companies use EBITDA as a primary metric which reflects company's performance (Isidro and Marques, 2008). As a surrogate of cash flows EBITDA is also used in an analysis of risk related to operating leverage (Parrino and Kidwell, 2009).

Advocates of EBITDA tend to emphasize its comparability, particularly as compared to other profit measures. They argue that depreciation and amortization charges are prone to subjective judgments. Accordingly, firms may boost earnings by aggressively extending the assets' useful lives (Epstein, 2009; Demerjian, 2009). The opponents of EBITDA, however, argue that depreciation and amortization constitute real costs which should not be neglected (Palepu et al., 2004). Also, Rozenbaum (2014) found that managers' reliance on EBITDA leads them to overinvest. Accordingly, the critics of EBITDA emphasize that this metric may be particularly misleading in the case of capital-intensive firms, where depreciable assets constitute the primary value drivers (Penman, 2007).

Some studies found that EBITDA may be less useful in measuring credit risk than income before extraordinary items and operating profit (Li, 2016). The other studies found that firms near thresholds of EBITDA-based ratios are more likely to reduce $R \& D$ and SG\&A expenditures (boosting EBITDA) prior to bond issuance (Begley, 2013). Also, firms with loan contracts that contain covenants based on EBITDA are more likely to misclassify core expenses as special items, in order to increase EBITDA (Fan et al., 2016). It is also argued that despite common belief 
EBITDA is not immune to inter-company differences in accounting principles (White et al., 2003). All this confirms that EBITDA, even if more immune (than operating profit) to distortions brought about by the subjectivity of depreciation and amortization, is prone to multiple reliability and comparability issues as well.

The literature discusses also potential flaws of EBITDA as a proxy for cash flows. Its tendency to overstate estimated cash flows is cited as the most serious pitfall (Mulford and Comiskey, 2005). This is because of the omission of changes in working capital, which may drain cash seriously, while not being taken into account by EBITDA (Fridson and Alvarez, 2002). Despite all these drawbacks, EBITDA is used much more frequently, as compared to cash flows, as a performance measure in debt covenants measurement (Li, 2016; Demiroglu and James, 2010).

Cash flows, however, are prone to significant problems as well (Zhang 2008). The reliability of operating cash flows may be eroded by (among others): aggressive capitalization of operating costs as fixed assets, sales of receivable accounts in factoring transactions, liquidations of inventories in "fire sales", aggressive extensions of payment terms of operating liabilities or loans granted to customers and treated as financial investments (rather than increases in trade receivables). Due to these issues, the research on the usefulness of cash flows in financial distress prediction produced somewhat mixed results. Many researchers indeed found that various cash flow-based ratios are statistically significant predictors of the forthcoming bankruptcy (Ohlson, 1980; Gentry et al., 1985; Casey and Bartczak, 1985; Ward and Foster, 1997; Bhandari and Iyer, 2013; Unegbu and Adefila, 2013; Khan and Guruli, 2015). However, Gupta et al. (2012), in their study of British small and medium-sized enterprises, found that the presence of operating cash flow information does not improve the prediction accuracy of the distress prediction models.

\section{Data and Methodology}

In this paper EBITDA-based and cash flow-based coverage ratios are compared, as financial distress prediction tools, in a sample of firms listed on the Warsaw Stock Exchange. The EBITDA is investigated in its two variants: one based on a raw operating profit (as reported in the company's income statement) and another one based on profit on sales (which is deemed to be less prone to distorting oneoff factors and subjective judgments). Similarly, operating cash flows are analysed in two variants: one based on raw operating cash flows (as reported in the company's cash flow statement) and another one based on operating cash flows adjusted for changes in operating liabilities (which may artificially boost total operating cash flows of firms in distress, if they deliberately cease repayments of 
their operating payables). Accordingly, the following four alternative liabilitiescoverage ratios have been investigated:

- Raw EBITDA to total liabilities = (operating profit + depreciation and amortization in a year) / total liabilities and provisions at the end of the year

- Core EBITDA to total liabilities = (profit on sales + depreciation and amortization in a year) / total liabilities and provisions at the end of the year,

- Raw OCF to total liabilities = operating cash flows in a year / total liabilities and provisions at the end of the year.

- Core OCF to total liabilities = (operating cash flows - change in operating liabilities in a year) / total liabilities and provisions at the end of the year.

The data from a period between the beginning of 2009 and the end of the first half of 2016 have been used. Within this timeframe, as many as 92 public firms faced at least one bankruptcy filing. The companies included in that sample, labelled further as "bankrupt firms", form the primary sub-sample. To enable a statistical analysis, this sample has been extended by adding 92 randomly selected firms, in which case no any bankruptcy filing was announced in the same period (this subsample is further denoted as "healthy firms" or "non-bankrupt firms"). All the accounting numbers used in this study have been collected from primary sources, that is from annual reports issued by the companies included in the sample.

Table 1 provides a breakdown of the whole sub-sample of bankrupt firms by their industry memberships, while Table 2 displays a time-series distribution of the underlying bankruptcy filings. As might be seen, no any individual industry seems to dominate, although two leading businesses make up over $28 \%$ of investigated bankruptcy filings. It seems therefore that the sample of corporate failures, included in this study, may be considered representative of a broad spectrum of diverse Polish companies. In contrast, a time-series breakdown shows that two years of economic slowdown (2012-2013) seem to be over-represented, while other periods, particularly those featured by relatively fast growth of Polish economy $(2010,2011,2014)$, seem to be under-represented. However, it seems fully logical, because bankruptcy rates tend to rise / fall when macroeconomic conditions deteriorate / improve.

It is worth noting, when discussing the size and the breakdown of the investigated sample, that the total number of failed firms included in the sample (i.e. 92 firms) has a significant share in the whole universe of Polish public companies. At the end of 2016 over 800 firms were listed on the Warsaw Stock Exchange (on both its primary market as well as the NewConnect market), which implies relatively high frequency of bankruptcies (over $10 \%$ of listed firms). Such a high rate of corporate failures observed on the Polish capital market entails high investment 
risk for shareholders and confirms the relevance of rigorous credit risk analysis in making stock investment decisions.

\section{Tab. 1 Breakdown of investigated bankruptcy filings by industry memberships}

\begin{tabular}{|c|c|c|}
\hline Industry & $\begin{array}{l}\text { Number of } \\
\text { observations }\end{array}$ & $\begin{array}{l}\text { Share in } \\
\text { a sample (in \%) }\end{array}$ \\
\hline Construction \& Engineering & 17 & 18,5 \\
\hline IT technologies & 9 & 9,8 \\
\hline Distribution of foodstuffs & 7 & 7,6 \\
\hline Real estate investments & 7 & 7,6 \\
\hline Energy & 5 & 5,4 \\
\hline Financial services & 5 & 5,4 \\
\hline Manufacture of industrial goods & 4 & 4,3 \\
\hline Restaurants & 4 & 4,3 \\
\hline Distribution of software and hardware & 4 & 4,3 \\
\hline Distribution of vehicles and car parts & 3 & 3,3 \\
\hline Apparel stores & 3 & 3,3 \\
\hline Distribution of heavy industrial goods & 2 & 2,2 \\
\hline Distribution of other consumer goods & 2 & 2,2 \\
\hline Food production & 2 & 2,2 \\
\hline Manufacture of durable consumer goods & 2 & 2,2 \\
\hline Manufacture of glass products & 2 & 2,2 \\
\hline Manufacture of pharmaceuticals and cosmetics & 2 & 2,2 \\
\hline Manufacture of wood and wooden products & 2 & 2,2 \\
\hline Marketing services & 2 & 2,2 \\
\hline Waste management & 2 & 2,2 \\
\hline Distribution of medical equipment & 1 & 1,1 \\
\hline Distribution of pharmaceuticals & 1 & 1,1 \\
\hline Healthcare services & 1 & 1,1 \\
\hline Leisure services & 1 & 1,1 \\
\hline Telecommunication services & 1 & 1,1 \\
\hline Transportation services & 1 & 1,1 \\
\hline Total & 92 & 100,0 \\
\hline
\end{tabular}

Source: Authorial computations on the basis of the annual financial statements published by the companies included in the sample. 
Tab. 2 Time-series distribution of investigated bankruptcy filings

\begin{tabular}{lll}
\hline Year & $\begin{array}{l}\text { Number of } \\
\text { observations }\end{array}$ & $\begin{array}{l}\text { Share in } \\
\text { a sample (in \%) }\end{array}$ \\
\hline 2009 & 11 & 12,0 \\
2010 & 4 & 4,3 \\
2011 & 5 & 5,4 \\
2012 & 25 & 27,2 \\
2013 & 21 & 22,8 \\
2014 & 10 & 10,9 \\
2015 & 12 & 13,0 \\
First half of 2016 & 4 & 4,3 \\
\hline Total & $\mathbf{9 2}$ & $\mathbf{1 0 0 , 0}$
\end{tabular}

Source: Authorial computations on the basis of the annual financial statements published by the companies included in the sample.

Table 3 presents selected financial statement data, averaged for bankrupt and healthy firms, which enable a comparison of their financial profiles. As might be seen, the bankrupt firms tend to be much smaller (in terms of revenues and total assets) than the healthy ones, much less profitable (on both operating profit and net earnings level) and having much lower share of shareholder's equity in the capital structure.

\section{Tab. 3 Comparison of selected financial statement data for bankrupt and} non-bankrupt firms included in the sample

\begin{tabular}{lll}
\hline \multirow{2}{*}{$\begin{array}{l}\text { Data in thousands } \\
\text { of PLN }\end{array}$} & $\begin{array}{l}\text { Bankrupt } \\
\text { firms }\end{array}$ & $\begin{array}{l}\text { Non-bankrupt } \\
\text { firms }\end{array}$ \\
\hline Sales revenues* & 51.414 & 189.886 \\
Operating profit* & -1.908 & 13.062 \\
Net earnings* & -3.147 & 8.830 \\
Total assets** & 55.176 & 228.606 \\
Shareholder's equity** & 8.744 & 110.871 \\
\hline
\end{tabular}

Source: Authorial computations on the basis of the annual financial statements published by the companies included in the sample.

Note: * in the last full financial year before the bankruptcy filing (in the case of bankrupt firms); ** at the end of the last full financial year before the bankruptcy filing (in the case of bankrupt firms).

One-period-ahead bankruptcy prediction horizon has been investigated. To make sure that only data which were publicly available on the bankruptcy filing date are taken into account, for bankruptcy filings announced between the beginning of 
April and the end of December of $t$-th year (i.e. when annual financial statements for the preceding year have already been published), data from annual reports for $t-1$ period have been used. In contrast, for bankruptcy filings announced between the beginning of January and the end of March of $t$-th year, data from annual reports for $t-2$ period have been used (as the most recent annual financial information available).

The research was conducted in four steps. First, medians of four liabilitiescoverage ratios within both sub-samples have been compared and the statistical significance of differences between those medians has been checked. Then, four univariate logit models for bankruptcy prediction have been estimated, each with one liability-coverage ratio as the only explanatory variable. In the third step the estimated logit models have been evaluated in terms of their in-sample prediction accuracy. Finally, on the ground of the estimated models the safety thresholds for liabilities-coverage ratios have been simulated.

To avoid possible distortions of model parameters, brought about by outlying observations (i.e. companies with unusually high or low values of liabilitiescoverage ratios), all four logit regressions were estimated on the samples which exclude outliers. In the case of all ratios an inter-quartile range rule has been applied in identifying outliers. However, in the third step of the research the whole original sample (i.e. including outliers) has been used. In classifying firms as bankrupt or healthy ones an arbitrary threshold for bankruptcy probability, equalling $50 \%$, has been assumed.

\section{Results and Discussion}

Table 4 presents medians as well as additional statistics computed for all four investigated ratios. As expected, bankrupt firms tend to have substantially lower values of all four ratios, as compared to non-bankrupt companies. Wilcoxon RankSum test statistics, which exceed a critical value of two, confirm that both subsamples differ significantly in terms of median values of all four ratios. The additional statistics inform that all four ratios show significant variations not only between bankrupt and healthy firms, but also within both groups of companies.

Table 5 and Table 6 display the EBITDA-based and cash flow-based logit models, respectively. 
Jacek, W.: EBITDA vs. Cash Flows in Bankruptcy Prediction on the Polish Capital Market.

Tab. 4 Selected statistics for four alternative liabilities-coverage ratios within sub-samples of bankrupt and healthy firms

\begin{tabular}{|c|c|c|c|c|c|c|}
\hline \multicolumn{2}{|l|}{ Statistics } & \multicolumn{2}{|c|}{$\begin{array}{l}\text { Raw } \\
\text { EBITDA / } \\
\text { total } \\
\text { liabilities }\end{array}$} & $\begin{array}{l}\text { Core } \\
\text { EBITDA / } \\
\text { total } \\
\text { liabilities }\end{array}$ & $\begin{array}{l}\text { Raw } \\
\text { OCF / } \\
\text { total } \\
\text { liabilities }\end{array}$ & $\begin{array}{l}\text { Core } \\
\text { OCF / } \\
\text { total } \\
\text { liabilities }\end{array}$ \\
\hline \multirow{2}{*}{ Median } & Bankrupt & \multicolumn{2}{|c|}{$0,7 \%$} & $1,1 \%$ & $-0,4 \%$ & $-3,1 \%$ \\
\hline & Non-bankrupt & \multicolumn{2}{|c|}{$19,4 \%$} & $19,2 \%$ & $13,6 \%$ & $11,3 \%$ \\
\hline \multirow{2}{*}{$\begin{array}{l}\text { Arithmetic } \\
\text { mean }\end{array}$} & Bankrupt & \multicolumn{2}{|c|}{$-5,1 \%$} & $-1,8 \%$ & $-0,9 \%$ & $-7,4 \%$ \\
\hline & Non-bankrupt & \multicolumn{2}{|c|}{$31,6 \%$} & $31,5 \%$ & $22,9 \%$ & $21,4 \%$ \\
\hline \multirow{2}{*}{$\begin{array}{l}\text { Standard } \\
\text { deviation }\end{array}$} & Bankrupt & \multicolumn{2}{|c|}{$28,2 \%$} & $20,9 \%$ & $35,6 \%$ & $42,7 \%$ \\
\hline & Non-bankrupt & \multicolumn{2}{|c|}{$44,8 \%$} & $44,8 \%$ & $44,8 \%$ & $40,4 \%$ \\
\hline \multicolumn{2}{|c|}{$\begin{array}{l}\text { Wilcoxon Rank-Sum test } \\
\text { statistic for the difference } \\
\text { between two medians* }\end{array}$} & \multicolumn{2}{|c|}{7,23} & 7,63 & 5,44 & 5,69 \\
\hline \multicolumn{7}{|c|}{$\begin{array}{l}\text { Source: Authorial computations on the basis of the annual financial statements publ } \\
\text { by the companies included in the sample. } \\
\text { Note: * value above two means that the difference between medians is statistically } \\
\text { significant at } 5 \% \text { significance level. }\end{array}$} \\
\hline \multicolumn{7}{|c|}{$\begin{array}{l}\text { Tab. } 5 \text { Parameters of EBITDA-based logit models and analysis of their } \\
\text { bankruptcy prediction accuracy }\end{array}$} \\
\hline \multirow{2}{*}{\multicolumn{2}{|c|}{ Statistics }} & \multicolumn{3}{|c|}{$\begin{array}{l}\text { Logit model with raw } \\
\text { EBITDA ratio }\end{array}$} & \multicolumn{2}{|c|}{$\begin{array}{l}\text { Logit model with core } \\
\text { EBITDA ratio }\end{array}$} \\
\hline & & & Coefficient & $t$-Statistic & Coefficient & $t$-Statistic \\
\hline \multicolumn{2}{|l|}{ Intercept } & & 0,73 & 3,08 & 1,01 & 4,25 \\
\hline \multicolumn{2}{|l|}{ Slope } & & $-6,39$ & $-6,40$ & $-8,66$ & $-7,24$ \\
\hline \multicolumn{2}{|l|}{ F statistic } & \multicolumn{3}{|c|}{40,94} & \multicolumn{2}{|l|}{52,38} \\
\hline \multicolumn{3}{|c|}{$\begin{array}{l}\text { Number of observations, after } \\
\text { removal of outliers }\end{array}$} & \multicolumn{2}{|c|}{$\begin{array}{l}165 \text { ( } 83 \text { bankrupt / } 82 \text { non- } \\
\text { bankrupt) }\end{array}$} & \multicolumn{2}{|c|}{$\begin{array}{l}165 \text { ( } 86 \text { bankrupt / } 79 \text { non- } \\
\text { bankrupt) }\end{array}$} \\
\hline \multicolumn{3}{|c|}{$\begin{array}{l}\text { Correctly predicted: } \\
\text { bankrupt* }\end{array}$} & \multicolumn{2}{|l|}{$76,09 \%$} & \multicolumn{2}{|l|}{$77,17 \%$} \\
\hline \multicolumn{3}{|c|}{ Correctly predicted: healthy* } & \multicolumn{2}{|l|}{$76,09 \%$} & \multicolumn{2}{|l|}{$70,65 \%$} \\
\hline \multicolumn{3}{|c|}{ Correctly predicted: total* } & \multicolumn{2}{|l|}{$76,09 \%$} & \multicolumn{2}{|l|}{$73,91 \%$} \\
\hline
\end{tabular}

Source: Authorial computations on the basis of the annual financial statements published by the companies included in the sample.

Note: * within the whole sample of 92 bankrupt and 92 non-bankrupt firms; a threshold of probability of $50 \%$ has been assumed for classification of companies. 
All models are significant (with double digit values of F-statistics). As expected, slope coefficients are negative for all four ratios. The general prediction accuracy (in the range between $66 \%$ and $76 \%$ ) of all models seems to be surprisingly good, given that they were estimated on the ground of samples which include firms from diverse industries and given that only one ratio is used as an explanatory variable in each model. The estimated models would probably perform even better, if other fundamental drivers of corporate credit risk (e.g. indebtedness ratio, current ratio, structure of assets or variability of cash flows) are added to the set of explanatory variables, i.e. when multi-variable logit models are built.

In terms of accuracy of predictions, at the arbitrarily assumed probability threshold of $50 \%$ the EBITDA-based models clearly outperform those based on operating cash flows, both within whole samples as well as within sub-samples of bankrupt firms only. It is also worth noting that in the case of two out of four models the accuracy of prediction of bankrupt firms exceeds the accuracy of predictions for healthy ones. To conclude, the investigated data do not confirm the supremacy of cash flows over accounting profits in predicting financial distress, with oneperiod-ahead forecast horizon.

\section{Tab. 6 Parameters of cash flow-based logit models and analysis of their bankruptcy prediction accuracy}

\begin{tabular}{lllll}
\hline \multirow{2}{*}{ Statistics } & \multicolumn{2}{l}{$\begin{array}{l}\text { Logit model with raw OCF } \\
\text { ratio }\end{array}$} & $\begin{array}{l}\text { Logit model with core OCF } \\
\text { ratio }\end{array}$ & \\
\cline { 2 - 5 } & Coefficient & $\boldsymbol{t}$-Statistic & Coefficient & $\boldsymbol{t}$-Statistic \\
\hline Intercept & 0,56 & 2,24 & 0,20 & 0,85 \\
Slope & $-7,22$ & $-5,06$ & $-5,97$ & $-4,53$ \\
\hline F statistic & 25,57 & 20,51 & \\
\hline Number of observations, after & $152(77$ bankrupt / 75 non- & $153(74$ bankrupt / 79 non- \\
removal of outliers & bankrupt) & bankrupt) & \\
\hline Correctly predicted: bankrupt* & $71,26 \%$ & $66,67 \%$ & \\
Correctly predicted: healthy* & $61,96 \%$ & $71,74 \%$ & \\
Correctly predicted: total* & $66,48 \%$ & $69,27 \%$ & \\
\hline
\end{tabular}

Source: Authorial computations on the basis of the annual financial statements published by the companies included in the sample.

Note: * within the whole sample of 92 bankrupt and 92 non-bankrupt firms; a threshold of probability of $50 \%$ has been assumed for classification of companies.

Finally, safety thresholds for the raw ratios (meant as values of ratios at which the probability of bankruptcy exceeds $50 \%$ ) have been estimated, on the ground of the logit models discussed above. According to those estimates, to keep a company 
sustainable, its managers should ensure that EBITDA covers no less than 11-12\% of carrying amount of total liabilities, but preferably no less than $15-20 \%$ (to keep the risk of illiquidity significantly lower than 50\%). In the case of the cash flowbased coverage ratio, its safety threshold seems to lie near 7-8\%. Its value above $15 \%$ / below $5 \%$ suggests remote / increased risk of insolvency.

\section{Conclusions}

In this paper the usefulness of EBITDA-based and cash flow-based liabilitiescoverage ratios in bankruptcy prediction has been evaluated. The study is based on data of Polish companies, in which case a bankruptcy filing was announced in the period between the beginning of 2009 and the end of the first half of 2016. This sample has been examined on the background of the counter-sample of randomly selected non-bankrupt firms. The analysis confirmed the usefulness of both EBITDA-based and cash flow-based ratios in a bankruptcy prediction. Even though both sub-samples cover wide variety of businesses, the logit models with only one ratio used as an explanatory variable are capable of correctly identifying bankrupt and healthy firms in about $66-76 \%$ of cases. This research, however, do not confirm the supremacy of operating cash flows over EBITDA in predicting financial distress. Thus, the obtained findings are relevant for financial statement users, because they constitute another evidence that financial numbers prepared on an accrual basis of accounting (i.e. coming from an income statement) are not unequivocally inferior to cash flows in credit risk analysis.

It is worth noting, when interpreting the obtained empirical results, that the sample investigated in this study is not homogenous in terms of the accounting standards applied by individual companies. This is so because under Polish regulations firms listed on the primary (regulated) segment of the Warsaw Stock Exchange, which publish consolidated financial statements, are obliged to apply International Financial Reporting Standards, while companies whose shares are traded on a secondary market (NewConnect) are allowed to apply Polish Accounting Bill. Consequently, individual firms included in the sample different significantly in the accounting policies they follow. However, this inter-company diversity of the financial reporting standards does not invalidate the obtained empirical findings. Quite the reverse: it only confirms that liabilities-coverage ratios are useful in corporate credit risk analysis, even when comparing firms operating in different accounting environments.

However, this study has some limitations. First of all, the eight-year period covered by the research is pretty short and embraces only few incomplete business cycles. During those years Polish economy did not experience any single year of recession. This means that the results can be biased. In particular, it is likely that 
the obtained estimates understate the safety thresholds of the investigated liabilities-coverage ratios. Another limitation stems from the fact that the examined ratios have been computed on the ground of annual reports only, instead of the most recent quarterly reports. This may reduce the predictive accuracy of the estimated bankruptcy prediction models to some extent.

\section{References}

Bancel, F., Mittoo, U. R., 2014. The Gap Between Theory and Practice of Firm Valuation: Survey of European Valuation Experts. Journal of Applied Corporate Finance 26, 106-117. DOI: 10.2139/ssrn.2420380.

Beatty, A., Cheng, L., Zach, T., 2015. Non-Recurring Items in Debt Contracts. SSRN Electronic Journal. DOI: 10.2139/ssrn.2595800.

Beatty, A., Dichev, I. D., Weber, J., 2012. The role and characteristics of accounting-based performance pricing in private debt contracts. SSRN Electronic Journal. DOI: 10.2139/ssrn.318399.

Begley, T., 2013. The Real Costs of Corporate Credit Ratings. Working Paper No. 1230. Ross School of Business. DOI: 10.2139/ssrn.2404290.

Bhandari, S., Iyer, R., 2013. Predicting Business Failure Using Cash Flow Statement Based Measures. Managerial Finance 7, 667-676. DOI: 10.1108/ 03074351311323455.

Casey, C., Bartczak, N., 1985. Using Operating Cash Flow Data to Predict Financial Distress: Some Extensions. Journal of Accounting Research 1, 384-401. DOI: $10.2307 / 2490926$.

Demerjian, P., 2009. Information, Monitoring, and Manipulation: The Economic Role of Covenant Measurement. SSRN Electronic Journal. DOI: 10.2139/ ssrn.1463482.

Demiroglu, C., James, C., 2010. The Information Content of Bank Loan Covenants. The Review of Financial Studies 10, 3700-3737. DOI: 10.1093/ rfs/hhq054.

Epstein, L., 2009. The Complete Idiot's Guide to Value Investing. Penguin Group, New York.

Fan, Y., Thomas, W. B., Yu, X., 2016. The Impact of Financial Covenants in Private Loan Contracts on Classification Shifting. SSRN Electronic Journal. DOI: $10.2139 / \mathrm{ssrn} .2675191$.

Fernandez, P., 2002. Valuation Using Multiples. How Do Analysts Reach Their Conclusions? Valuation Methods and Shareholder Value Creation, 145-167. DOI: 10.1016/b978-012253841-4.50021-4. 
Jacek, W.: EBITDA vs. Cash Flows in Bankruptcy Prediction on the Polish Capital Market.

Fridson, M., Alvarez, F., 2002. Financial Statement Analysis. A Practitioner's Guide. John Wiley \& Sons, New York.

Gentry, J. A., Newbold, P., Whitford, D. T., 1985. Predicting Bankruptcy: If Cash Flow's Not the Bottom Line, What Is? Financial Analyst Journal 5, 47-58. DOI: 10.2469/faj.v41.n5.47.

Gray, W., Vogel, J., 2012. Analyzing Valuation Measures: A Performance HorseRace Over the Past 40 Years. SSRN Electronic Journal. DOI: 10.2139/ ssrn. 1970693.

Greenwald, B. C. N., Kahn, J., Sonkin, P. D., Van Biema, M., 2001. Value Investing. From Graham to Buffett and Beyond. John Wiley \& Sons, New York.

Gupta, J., Wilson, N., Gregoriou, A., Healy, J., 2014. The Value of Operating Cash Flow in Modeling Credit Risk for SMEs. Applied Financial Economics 9, 649-660. DOI: 10.1080/09603107.2014.896979.

Hughen, J.C., Strauss, J., 2016. Portfolio Allocations Using Fundamental Ratios: Are Profitability Measures Effective in Selecting Firms and Sectors? SSRN Electronic Journal. DOI: 10.2139/ssrn.2699948.

Isidro, H., Marques, A., 2008. Non-GAAP Financial Disclosures: Evidence from European firms' press releases. SSRN Electronic Journal. DOI: 10.2139/ ssrn. 1266667.

Khan, A. H., Guruli, M. R., 2015. Predicting Bankruptcy by Liquidity Ratios Analysis. Journal UMP Social Sciences and Technology Management 3, 372-380.

Li, N., 2016. Performance Measures in Earnings-Based Financial Covenants in Debt Contracts. Journal of Accounting Research 4, 1149-1186. DOI: 10.1111/ 1475-679x.12125.

Lie, H., Lie, E., 2002. Multiples Used to Estimate Corporate Value. Financial Analyst Journal 2, 44-54. DOI: 10.2469/faj.v58.n2.2522.

Mulford, C. W., Comiskey, E. E., 2002. The Financial Numbers Game. Detecting Creative Accounting Practices. John Wiley \& Sons, New York.

Mulford, C. W., Comiskey, E. E., 2005. Creative Cash Flow Reporting. Uncovering Sustainable Financial Performance. John Wiley \& Sons, Hoboken.

Ohlson, J. A., 1980. Financial Ratios and the Probabilistic Prediction of Bankruptcy. Journal of Accounting Research 1, 109-131. DOI: 10.2307/2490395.

Palepu, K. G., Healy, P. M., Bernard, V. L., 2004. Business Analysis \& Valuation Using Financial Statements. Thomson South-Western, Mason.

Parrino, R., Kidwell, D., 2009. Fundamentals of Corporate Finance. John Wiley \& Sons, Hoboken. 
Penman, S. H., 2007. Financial Statement Analysis and Security Valuation. McGraw-Hill, New York.

Rozenbaum, O., 2014. EBITDA Disclosure and Overinvestment in Capital. SSRN Electronic Journal. DOI: 10.2139/ssrn.2543934.

Unegbu, A., Adefila, J., 2013. Efficacy Assessments of Z-Score and Operating Cash Flow Insolvency Predictive Models. Open Journal of Accounting 3, 53-78. DOI: 10.4236/ojacct.2013.23009.

Verninmen, P., Quiry, P., Dallocchio, M., Le Fur, Y., Salvi, A., 2005. Corporate Finance Theory and Practice. John Wiley \& Sons, Chichester.

Ward, T. J., Foster, B. P., 1997. A Note on Selecting a Response Measure for Financial Distress. Journal of Business Finance and Accounting 6, 869-879. DOI: 10.1111/1468-5957.00138.

White, G. I., Sondhi, A. C., Fried, D., 2003. The Analysis and Use of Financial Statements. John Wiley \& Sons, Hoboken.

Zhang, W., 2008. Real Activities Manipulation to Meet Analysts' Cash Flow Forecasts. SSRN Electronic Journal. DOI: 10.2139/ssrn.1013228. 